\begin{tabular}{|l|l|l||}
\hline \multicolumn{2}{|c|}{ PublisherInfo } \\
\hline \hline PublisherName & $:$ & BioMed Central \\
\hline \hline PublisherLocation & $:$ & London \\
\hline \hline PublisherImprintName & $:$ & BioMed Central \\
\hline \hline
\end{tabular}

\title{
Counting vertebrate microRNAs
}

\begin{tabular}{|l|c|l||}
\hline \multicolumn{2}{|c|}{ ArticleInfo } \\
\hline \hline ArticleID & $:$ & 4718 \\
\hline \hline ArticleDOI & $:$ & $10.1186 /$ gb-spotlight-20030310-01 \\
\hline \hline ArticleCitationID & $:$ & spotlight-20030310-01 \\
\hline \hline ArticleSequenceNumber & $:$ & 70 \\
\hline \hline ArticleCategory & $:$ & Research news \\
\hline ArticleFirstPage & $:$ & 1 \\
\hline \hline ArticleLastPage & $:$ & 2 \\
\hline \hline & & RegistrationDate : 2003-3-10 \\
\hline ArticleHistory & $:$ & OnlineDate \\
\hline \hline ArticleCopyright & $:$ & BioMed Central Ltd2003-3-10 \\
\hline \hline ArticleGrants & $:$ & \\
\hline \hline ArticleContext & $:$ & 130594411 \\
\hline \hline
\end{tabular}




\section{Jonathan B Weitzman}

Email: jonathanweitzman@hotmail.com

MicroRNAs (miRNAs) are short non-coding RNAs that play a role in the control of gene expression. In the March 7 Science, Lee Lim and colleagues at the Massachusetts Institute of Technology report attempts to predict the total number of miRNAs in the human genome (Science 2003, 299:1540). They used a computational program called MiRscan to identify miRNA genes in vertebrate genomes by evaluating conserved stem loop structures. Around 15,000 potential stem loop structures were found in the human genome. MiRscan found a set of 188 human loci with high scores. This set includes 81 (74\%) out of 109 known human miRNAs. Lim et al. extrapolate to predict that the upper limit for the number of human miRNAs is 255 genes. Which implies that there are only another 40 or so miRNA genes yet to be found. When all these have been tracked down, the challenge will be to work out the precise functions of this large gene family.

\section{References}

1. An abundant class of tiny RNAs with probable regulatory roles in Caenorhabditis elegans.

2. Science, [http://www.sciencemag.org]

3. Massachusetts Institute of Technology, [http://www.mit.edu] 